\title{
SEASONAL AND SPATIAL PATTERNS OF TOXIGENIC SPECIES OF Dinophysis AND Pseudo-nitzschia IN A SUBTROPICAL BRAZILIAN ESTUARY
}

Carlos Eduardo Junqueira de Azevedo Tibiriçá*, Luciano Felício Fernandes and Luiz Laureno Mafra Junior

Universidade Federal do Paraná

(Av. Cel. Francisco H. dos Santos, S/N, 81531-990 Curitiba, PR, Brasil)

*Corresponding author: cejat87@uol.com.br

http://dx.doi.org/10.1590/S1679-87592015071906301

\begin{abstract}
A B S T R A C T
This study investigated the spatial and temporal distributions of toxigenic phytoplankton species between October 2010 and April 2012 in Guaratuba Bay, Paraná state, Brazil, where aquaculture has been intensified in recent years. The highest abundances of Pseudo-nitzschia calliantha and $P$. pungens (up to $7.3 \times 104$ cells $\mathrm{L}^{-1}$ ), diatoms which cause amnesic shellfish poisoning (ASP), were correlated with higher values of temperature (from December to April, salinity $(>20)$ and silicate concentrations (ranging from 6.0 to $90.0 \mu \mathrm{m}$ ). The occurrence of these harmful diatoms in the bay also appeared to depend upon the development of seeding mechanisms in the adjacent coastal water and its subsequent advection by tidal currents to the interior of the estuary. During the study period, Pseudo-nitzschia cell abundance remained low to moderate probably as a result of growth limitation by phosphate shortage, especially in the outer area of the estuary. In addition, harmful species of Dinophysis, dinoflagellates responsible for diarrhetic shellfish poisoning (DSP) events, were recorded in every sampling campaign. The highest abundances of D. acuminata, D. caudata and D. tripos were associated with the upper halocline layer in regions of the bay where water column stratification was more frequent. On some occasions, cell abundances of $D$. acuminata (up to $3.2 \times$ $10^{3}$ cells $\mathrm{L}^{-1}$ ) exceeded levels considered harmful in areas used to cultivate bivalve mollusks for human consumption. These novel results strongly indicate the necessity of implementing a monitoring program for harmful microalgae in Guaratuba Bay.
\end{abstract}

\section{RES UMO}

Este estudo investigou a distribuição espacial e temporal de espécies toxigênicas de fitoplâncton entre outubro de 2010 e abril de 2012 na Baía de Guaratuba, Estado do Paraná, Brasil, onde as atividades de maricultura têm se intensificado nos últimos anos. As maiores abundâncias de Pseudo-nitzschia calliantha e $P$. pungens (até 7,3 x 104 células $\mathrm{L}^{-1}$ ), diatomáceas causadoras do envenenamento amnésico por consumo de molusco (ASP), foram correlacionadas com valores mais elevados de temperatura (de dezembro a abril), salinidade (>20) e concentrações de silicato (variando de 6,0 a $90,0 \mu \mathrm{M})$. A ocorrência destas diatomáceas na baía aparentemente depende do desenvolvimento de mecanismo de inoculação na água costeira adjacente e de seu subsequente transporte pelas correntes de maré para o interior do estuário. Durante o período de estudo, no entanto, a abundância celular de Pseudo-nitzschia permaneceu baixa, provavelmente devido à limitação do crescimento por falta de fosfato, especialmente na área externa. Além disso, espécies nocivas de Dinophysis, um dinoflagelado responsável pela produção de toxinas diarreicas (DSP), foram registradas em todas as campanhas mensais de amostragem. As maiores abundâncias de D. acuminata, D. caudata e D. tripos foram associadas com a camada logo acima da haloclina, nas regiões da baía onde a estratificação da coluna de água foi mais frequente. Em algumas ocasiões, a abundância de células de D. acuminata (até $3,2 \times 10^{3}$ células $\mathrm{L}^{-1}$ ) em áreas utilizadas para cultivo de moluscos bivalves para consumo humano, superou níveis considerados perigosos. Estes resultados indicam a necessidade de implantação de um programa de monitoramento de microalgas nocivas na Baía de Guaratuba.

Descriptors: Harmful algal blooms, Phytoplankton ecology, Subtropical estuary, Diarrhetic toxins, Amnesic toxins.

Descritores: Florações de algas nocivas, Ecologia do fitoplâncton, Estuário subtropical, Toxinas diarreicas, Toxinas amnésicas. 


\section{INTRODUCTION}

Guaratuba Bay is a relatively pristine estuary, located in the subtropical region of Brazil, where oyster farming (Crassostrea spp.) has grown substantially in recent years (BALDAN; BENDHACK, 2009). The dependence of traditional communities on fishery products as well as an increase in the consumption of bivalve mollusks from this bay raises a concern about human poisoning due to the consumption of products contaminated with algal toxins (PERL et al., 1990; CARVALHO et al., 1998; DARANAS et al., 2001; REIZOPOULOU et al., 2008; ETHERIDGE, 2010). The fear that such events could occur in Guaratuba Bay is reinforced by the presence of toxin-producing microalgae in nearby locations, including that of species that cause diarrhetic shellfish poisoning (DSP) and amnesic shellfish poisoning (ASP) (MAFRA Jr. et al., 2006; ODEBRECHT et al., 2002; PROCOPIAK et al., 2006; PROENÇA, 2006; FERNANDES; BRANDINI, 2010; FERNANDES et al., 2013).

The main toxins responsible for DSP okadaic acid (OA) and its analogs, the dinophysistoxins (DTXs) — are produced by dinoflagellates of the genera Dinophysis and Prorocentrum (DARANAS et al., 2001; TOYOFUKU, 2006; GERSSEN et al., 2010). These toxins affect humans through the consumption of bivalve mollusks, which accumulate the toxic compounds in their tissues (REIZOPOULOU et al., 2008). Importantly, even at low cell densities (i.e., 1000 cells $\mathrm{L}^{-1}$ ), Dinophysis spp. can produce toxin concentrations sufficient to cause intoxication symptoms, such as nausea, abdominal cramps and diarrhea, in people who consume the contaminated bivalves (TOYOFUKU, 2006). In humans, DSP has been documented since the 1960s, and currently, high levels of $\mathrm{OA}$ are repeatedly found in coastal regions worldwide (GERSSEN et al., 2010). This toxin has already been found in the soft tissues of mollusks collected along the southeastern coast of Brazil (PROENÇA; MAFRA Jr., 2005; MARINÉ et al., 2009).

In addition to the DSP-causing toxins, domoic acid (DA) - the main toxin which causes ASP outbreaks, produced by several species of the diatom Pseudo-nitzschia (JEFFERY et al., 2004; GRANT et al., 2010) - has also been recorded in South Brazil (PROENÇA; MAFRA Jr., 2005). Domoic acid, which is responsible for massive mortalities of birds and marine mammals following the ingestion of contaminated fish (BELTRÀN et al., 1997; LEFEBVRE et al., 1999), can also intoxicate humans through the consumption of bivalve mollusks that accumulate the toxin in their tissues, mainly in the hepatopancreas and viscera (PERL et al., 1990;
GRANT et al., 2010; MAFRA et al., 2010). Although, only in special episodes, when a large number of Pseudo-nitzschia spp. cells containing high DA concentrations occur in coastal waters, are bivalve mollusks capable of accumulating sufficient toxin to affect humans, causing gastrointestinal and neurological symptoms (JEFFERY et al., 2004; GRANT et al., 2010). During the major 1987 Pseudonitzschia multiseries bloom on Prince Edward Island, Canada, more than 100 people were hospitalized, and four patients died (PERL et al., 1990).

In the coastal region and other estuaries surrounding Guaratuba Bay, harmful Dinophysis spp. and Pseudo-nitzschia species have already been recorded in abundances considered dangerous by monitoring programs (ODEBRECHT et al., 2002; MAFRA Jr. et al., 2006; PROENÇA et al., 2011; CIDASC, 2012). This bay is surrounded by seaside resorts and small- to medium-sized cities that can become densely populated in summer. The local economy is widely tied to small-scale fishing and tourism activities, which causes the bay area to become an ecosystem highly vulnerable to syndromes caused by microalgal toxins. Despite this vulnerability and the nearby occurrence of toxin-producing algal species, this study is the first to investigate the spatiotemporal variation of the potentially harmful Dinophysis spp. and Pseudo-nitzschia spp. in Guaratuba Bay.

\section{Material And Methods}

Study Area

Guaratuba Bay is located on the coast of

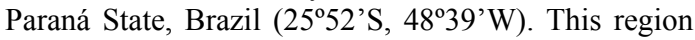
has a subtropical, humid, mesothermic climate, presenting a hot summer and lacking a dry season (Cfa-type in the Köppen classification). The driest period extends from May to August, with a mean monthly rainfall of 250 to $350 \mathrm{~mm}$ and a mean temperature of 16 to $17^{\circ} \mathrm{C}$ (IAPAR, 2012). Much of the inner edge of the bay is unpopulated, being surrounded by mangrove forests (SANTOS et al., 2008). This semi-enclosed coastal system is mainly influenced by the tide (up to $1.5 \mathrm{~m}$ ), but is also strongly affected by river discharge (MARONE et al., 2006). The main rivers draining into the bay are the Cubatão and São João, which together contribute a runoff of about $80 \mathrm{~m} \mathrm{~s}-1$ (MARONE et al., 2006). There are over 20 other minor rivers, of which the Parati, located on the north-south axis of the bay where oyster farming is concentrated, is the most important (Fig. 1). The shallow depths, the narrow but deep connection to the ocean and the extensive drainage basin (of approximately 1,700 $\mathrm{km}^{2}$ ) contribute to the occurrence of water column stratification, mainly in the periods subject to neap 
tides (MARONE et al., 2006). In fact, this bay is considered a partially stratified estuary according to the classification of DAY JR. et al. (1989).

\section{Sampling}

Sampling campaigns were undertaken approximately monthly between October 2010 and April 2012, covering two successive spring and summer seasons, the most favorable for the proliferation of harmful algae in southern Brazil (RÖRIG et al., 1998; MAFRA Jr. et al., 2006). Seven sampling stations were selected (Fig. 1) in Guaratuba Bay covering areas with commercial oyster farms and/or areas with the potential for the future expansion of such facilities. At each georeferenced station, the seawater was sampled with a Van Dorn bottle at the surface, near the bottom and, depending on the depth and the transparency of the water, in an intermediate stratum located at the base of the euphotic zone. Salinity, temperature, chlorophyll fluorescence and turbidity were measured along a vertical depth profile (at every $20 \mathrm{~cm}$ ) using a CTD (conductivity, temperature and depth meter) device (JFE ALEC Co. Ltd.®, model COMPAC-CTD). Vertical and/or oblique hauls were carried out using a phytoplankton net with a $20-\mu \mathrm{m}$ mesh size.

Analysis of Physical and Chemical Parameters

Samples collected with the Van Dorn bottle were filtered in 200-ml aliquots through a vacuum filtration system and used to determine the concentrations of dissolved nutrients by spectrophotometry and of chlorophyll- $a$ by fluorometry (HOLM-HANSEN et al., 1965). The latter analysis was only applied to selected samples and was used to calibrate the measurements obtained by a chlorophyll fluorescence sensor attached to the CTD. Additionally, dissolved ammonium and phosphate concentrations were determined according to STRICKLAND and PARSONS' method (1972), and the analysis of silicate, nitrite and nitrate concentrations followed the recommendations of APHA (1999). Concentrations of nitrite, nitrate and ammonium were summed up and expressed as dissolved inorganic nitrogen (DIN). Finally, silicate to DIN (Si:N) and DIN to phosphate $(\mathrm{N}: \mathrm{P})$ ratios were calculated.

\section{Phytoplankton Composition and Abundance}

Samples from the phytoplankton net were preserved in a formaldehyde solution at a final concentration of $4.0 \%$, and observed under a BX-30 light microscope coupled to an Olympus ${ }^{\circledR}$ DP-71 digital camera. Whenever Pseudo-nitzschia spp. cells were abundant, samples were prepared according to HASLE and FRYXELL (1970) for examination in a transmission electron microscope (TEM, model JEOL® JM1200 EXII).

For quantitative analysis, samples collected with the Van Dorn bottle were fixed with neutral Lugol's solution at a final concentration of approximately $1 \%$. Each sample was processed using the sedimentation method of ÜTERMOHL (1958). The cells were counted in accordance with Edler and Elbrächter's methodology (2010), covering the whole counting chamber to estimate the total abundance of cells in a sample volume ranging from 10 to $25 \mathrm{~mL}$.

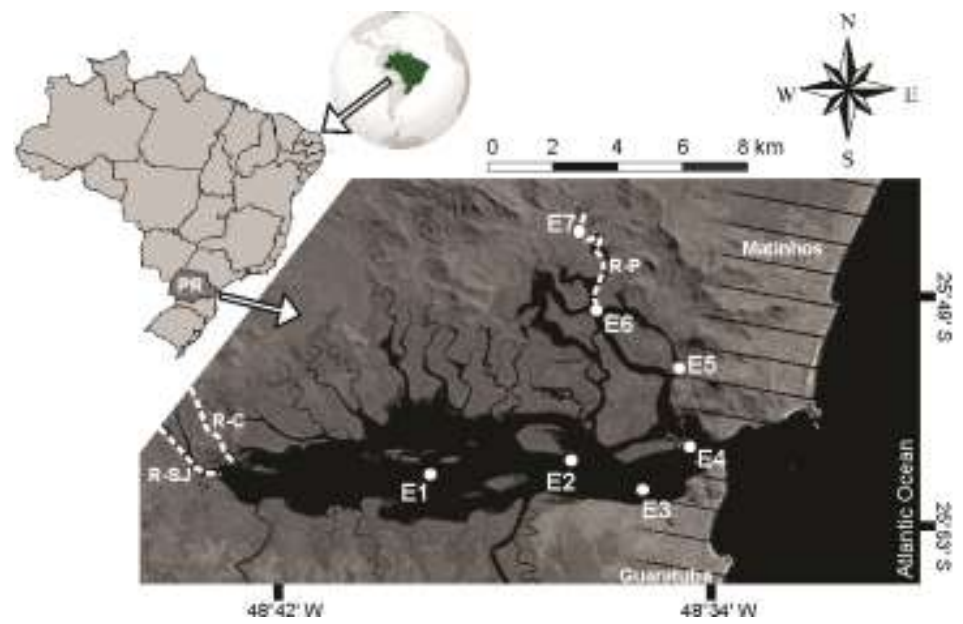

Fig. 1. Map of Guaratuba Bay, located in the state of Paraná (PR), Brazil. The sampling stations were designated E1 to E7. The following main rivers flowing into the bay are indicated with dotted lines: São João River (R-SJ), Cubatão River (R-C) and Parati River (R-P). Image source: USGS (http://www.usgs.gov/). 


\section{Treatment of Data and Statistical Analysis}

Descriptive analyses were used in the interpretation of results, complemented by canonical correspondence analysis (CCA). The CCA was performed with all the microphytoplankton taxa, the environmental variables of salinity, temperature, turbidity, and the concentrations of chlorophyll- $a$ and dissolved nutrients. The abundance data were transformed using the fourth root prior to the analysis. Monte Carlo permutations were performed to test the significance $(\mathrm{p}<0.05)$ of each environmental factor, with stepwise inclusion (forward selection) of only the significant factors in the model generated. For this analysis, the Canoco software for Windows 4.5 (Microcomputer Power, Inc., Ithaca, NY, USA) was used (TER BRAAK; SMILAUER, 2002).

\section{RESULTS}

Guaratuba Bay was characterized as a partially stratified estuary, with moderate to high concentrations of silicate $(>30 \mu \mathrm{M})$ and dissolved nitrogen $(>10 \mu \mathrm{M})$, especially in its innermost regions (salinity 0.0-15.0, E1 and E7) (Fig. 2). The highest chlorophyll- $a$ concentrations $\left(>3.0 \quad \mu g \quad L^{-1}\right)$ also occurred in this area. Conversely, water transparency was greater $(>1.3 \mathrm{~m})$ near the mouth of the estuary (E3-E4) due to the stronger influence of marine waters (Fig. 2). Phosphate concentration was lower $(<0.5$ $\mu \mathrm{M})$ in the sampling stations located along the eastwest axis of the bay (E1-E3), which received a greater fluvial contribution than did those along the southnorth axis (E5-E7) (Fig. 2).

The water temperature in Guaratuba Bay presented little spatial variability (data not shown) but varied seasonally from 16 to $30^{\circ} \mathrm{C}$ throughout the study period (Fig. 3). The increase in rainfall (Fig. 4) in the summer months modified the patterns of circulation and stratification in the bay and caused a reduction in the salinity and phosphate values, as well as an increase in the turbidity, silicate and chlorophyll$a$ concentrations (Fig. 3), which ultimately imposed significant changes on the phytoplankton composition and abundance (Fig. 5).

The main environmental parameters associated with the first canonical axis in the CCA analysis were rain, transparency (Secchi), salinity and nitrogen concentration on the positive side, and temperature and silicate concentration on the negative side (Fig. 5). On the second axis, the greatest salinity, turbidity, and dissolved inorganic nitrogen (DIN) values were placed on the negative side, while the higher values of temperature, $\mathrm{Si}: \mathrm{N}$, and rain were concentrated on the positive side. The Monte Carlo test was performed and revealed that all canonical axes proved significant $(\mathrm{p}<0.01)$. The first two ordination axes together explained $51.6 \%$ of the variation in the species-environment relation.
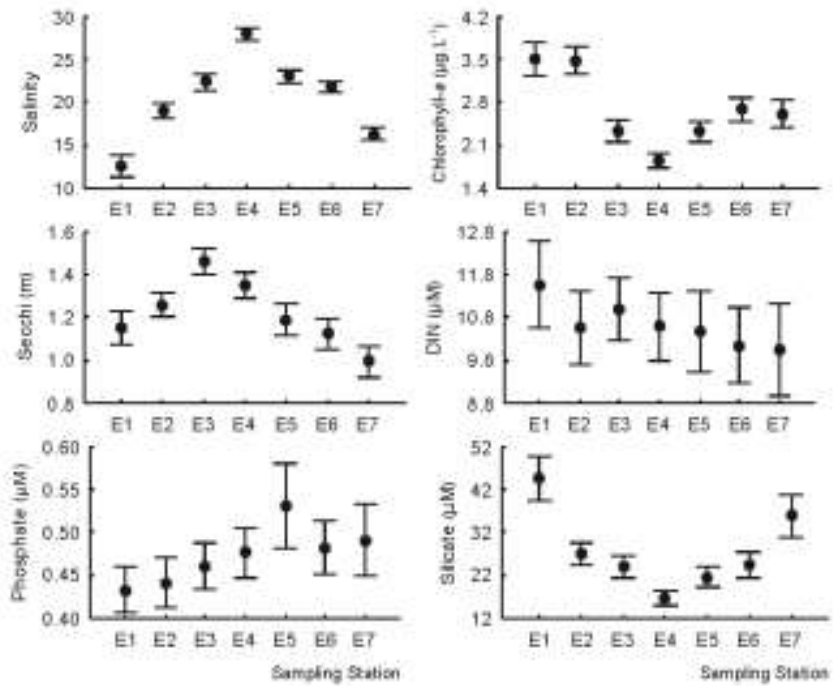

Fig. 2. Mean values and standard errors for salinity, water transparency (Secchi), and concentrations of chlorophyll- $a$, dissolved inorganic nitrogen (DIN), phosphate and silicate measured at seven sampling stations (X-axis) in Guaratuba Bay from October 2010 to April 2012. Sampling stations E1-E3 and E5-E7 fall on the east-west and north-south axes of the bay, respectively, and station E4 lies at the intersection of the two axes (see Fig. 1). 


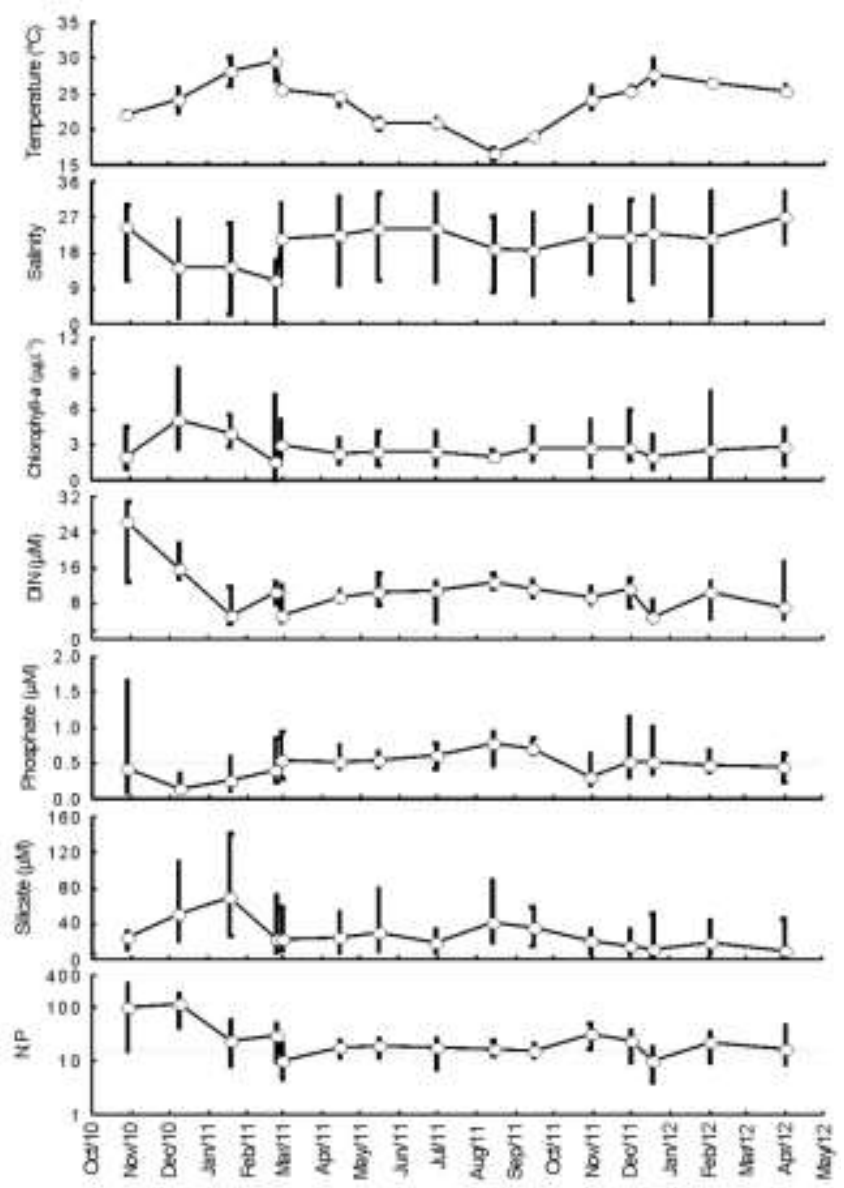

Fig. 3. Minimum, mean and maximum values for temperature, salinity, concentration of chlorophyll- $a$, dissolved inorganic nitrogen (DIN), phosphate, silicate and the ratio of nitrogen to phosphate (N:P) based on the 15 sampling campaigns (X axis) performed in Guaratuba Bay. The $\mathrm{Y}$ axis for $\mathrm{N}: \mathrm{P}$ is on logarithmic scale.

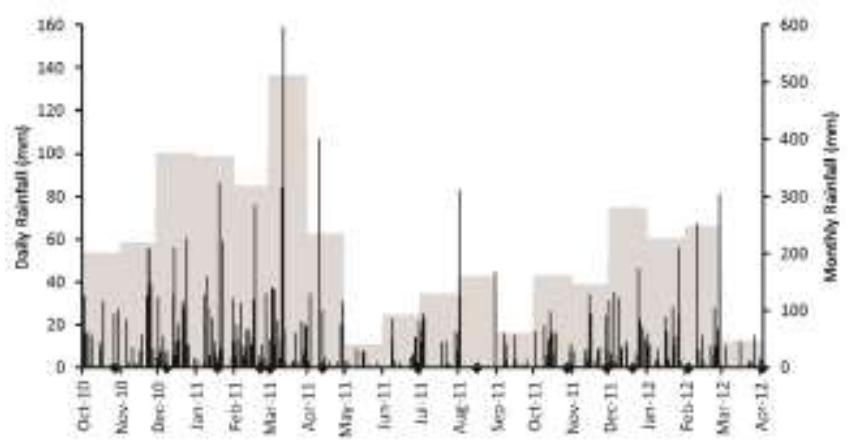

Fig. 4. Daily rainfall (left y-axis) recorded in Guaratuba Bay, PR, from September 2010 to April 2012. Markers on the bottom of the plot indicate the sampling dates, and the shaded bars indicate the monthly rainfall (right y-axis). Data from INMET (2012). 


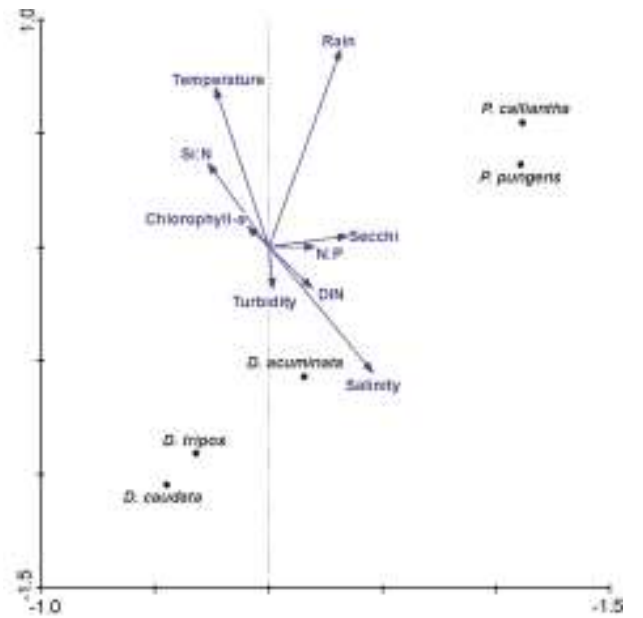

Fig. 5. Biplot of the canonical correspondence analysis (CCA) based on the cell abundance data of potentially toxic microalgae, namely Dinophysis spp. and Pseudo-nitzschia spp., and the following environmental variables: rainfall (Rain), temperature, salinity, turbidity, chlorophyll- $a$, water transparency (Secchi), dissolved inorganic nitrogen (DIN) and the ratios of DIN to phosphate $(\mathrm{N}: \mathrm{P})$ and of silicate to DIN (Si:N).
The silicate concentration in Guaratuba Bay was constantly high, with spatial or seasonal mean values always above $10 \mu \mathrm{M}$ (Fig. 2). The mean concentration of DIN was similarly high (>9.0 $\mu \mathrm{M})$, but the phosphate concentration was consistently low (0.1-0.9 $\mu \mathrm{M})$. As a result, on some occasions, N:P values were higher than 100 (Fig. 3), suggesting a growth limitation of phytoplankton due to a shortage of phosphorus, mainly under conditions of greater rainfall and/or increased chlorophyll- $a$ concentration (Fig. 3). Chlorophyll- $a$ values were generally low $(<4.0 \mu \mathrm{g} \mathrm{L}-1)$, indicating that the estuary can be classified as oligomesotrophic (Fig. 3)

Five potentially toxigenic species belonging to the Pseudo-nitzschia and Dinophysis genera were found in Guaratuba Bay during this study: Pseudonitzschia calliantha Lundholm, Moestrup \& Hasle, $P$. pungens (Grunow ex Cleve) Hasle, Dinophysis acuminata Claparède \& Lachmann, Dinophysis caudata Saville-Kent and Dinophysis tripos Gourret (Fig. 6).
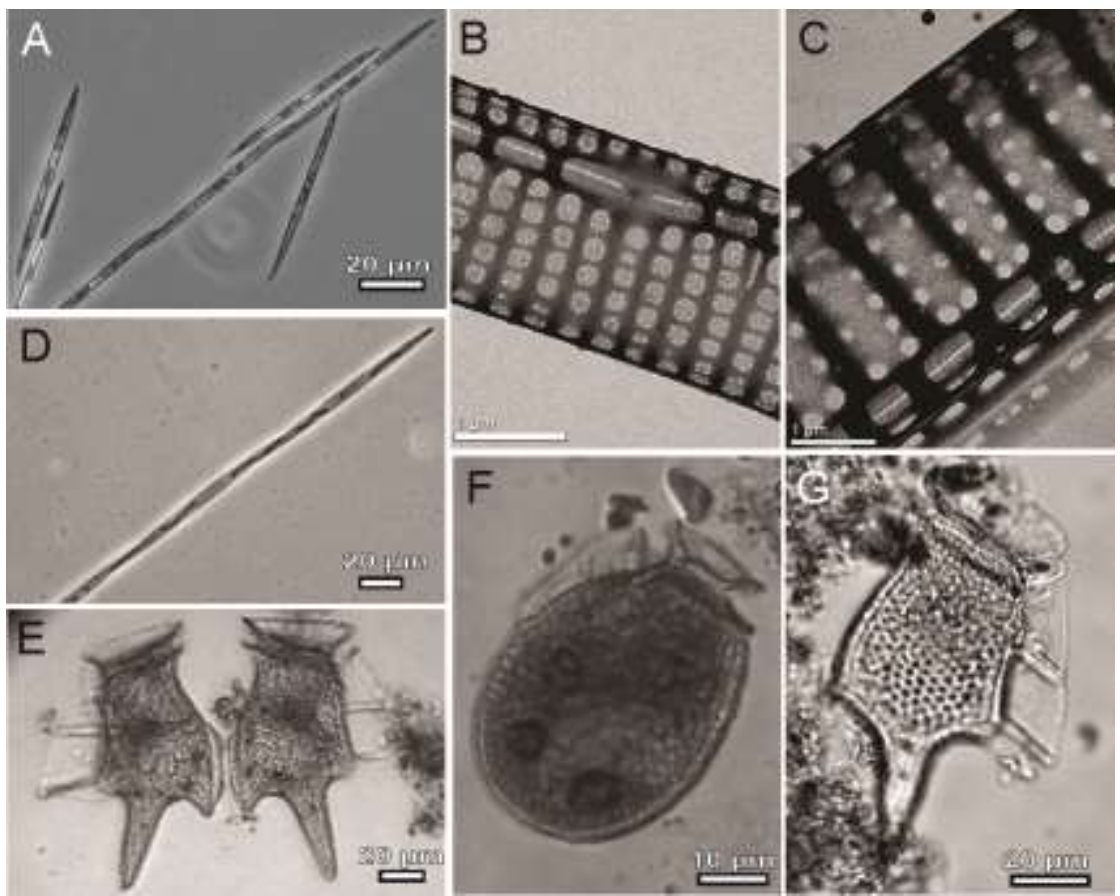

Fig. 6. Potentially toxic microalgal species identified in samples from Guaratuba Bay, PR by light microscopy (A, D-G) and transmission electron microscopy (B, C): (A, B) Pseudo-nitzschia calliantha, (C, D) P. pungens, (E) Dinophysis tripos, (F) D. acuminata, (G) D. caudata. 
$P$. calliantha reached abundances up to $7.3 \mathrm{x}$ 104 cells $\mathrm{L}^{-1}$, and was associated with salinities between 20 and 27 (Fig. 7). The maximum abundances of this species were recorded in December 2010 and April 2011, with lower cell density values recorded at other months (Fig. 8). P. pungens attained up to $2.6 \times 104$ cells $\mathrm{L}^{-1}$, associated with salinities between 18 and 27 (Fig. 7). The highest cell densities were recorded in December 2010 and April 2011, along with secondary peaks in October 2011 and
February 2012 (Fig. 8). Vertically, both P. pungens and $P$. calliantha were more abundant next to the bottom, below the halocline (Fig. 9). In the CCA, $P$. calliantha, $P$. pungens and some other taxa (mainly Bacillaria sp., Cerataulina pelagica, Guinardia spp. and Protoperidinium spp.) were grouped together under conditions of warm temperature, heavy rainfall and greater values of salinity, water transparency (Secchi), and Si:N (Fig. 5).

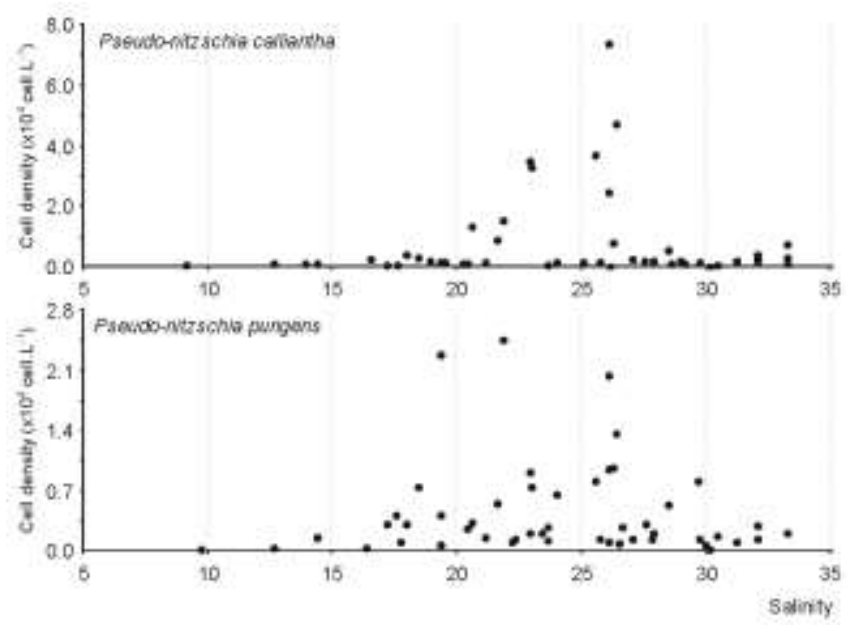

Fig. 7. Cell abundance of two potentially toxic Pseudo-nitzschia species versus salinity in all samples where they occur $(n=67)$ in Guaratuba Bay, PR, from October 2010 to April 2012.

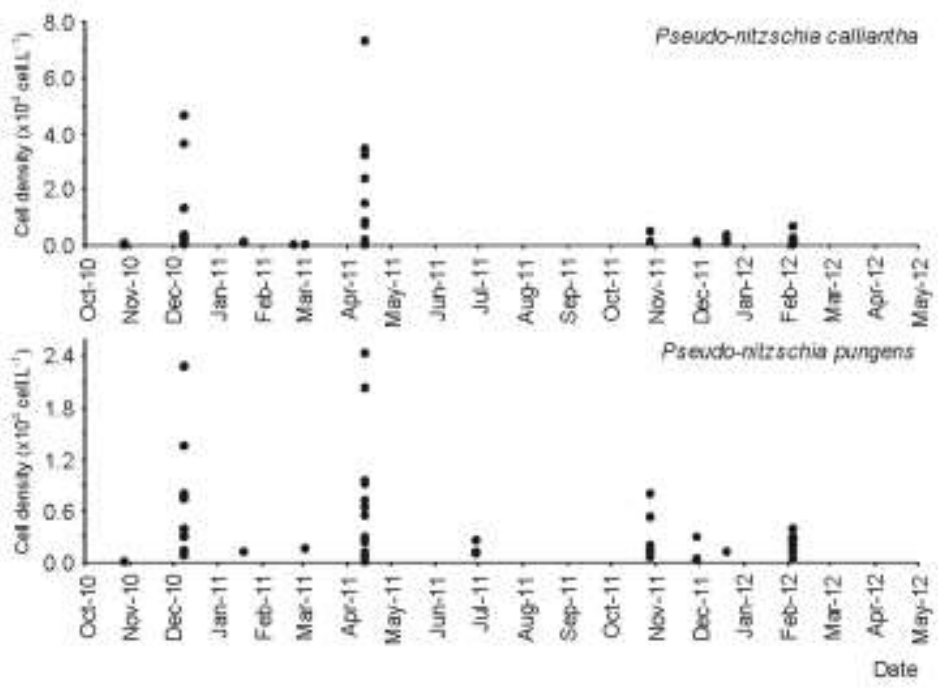

Fig. 8. Abundance of two potentially toxic Pseudo-nitzschia species (Y-axis) recorded in samples collected at each of the 15 sampling campaigns in Guaratuba Bay, PR. 


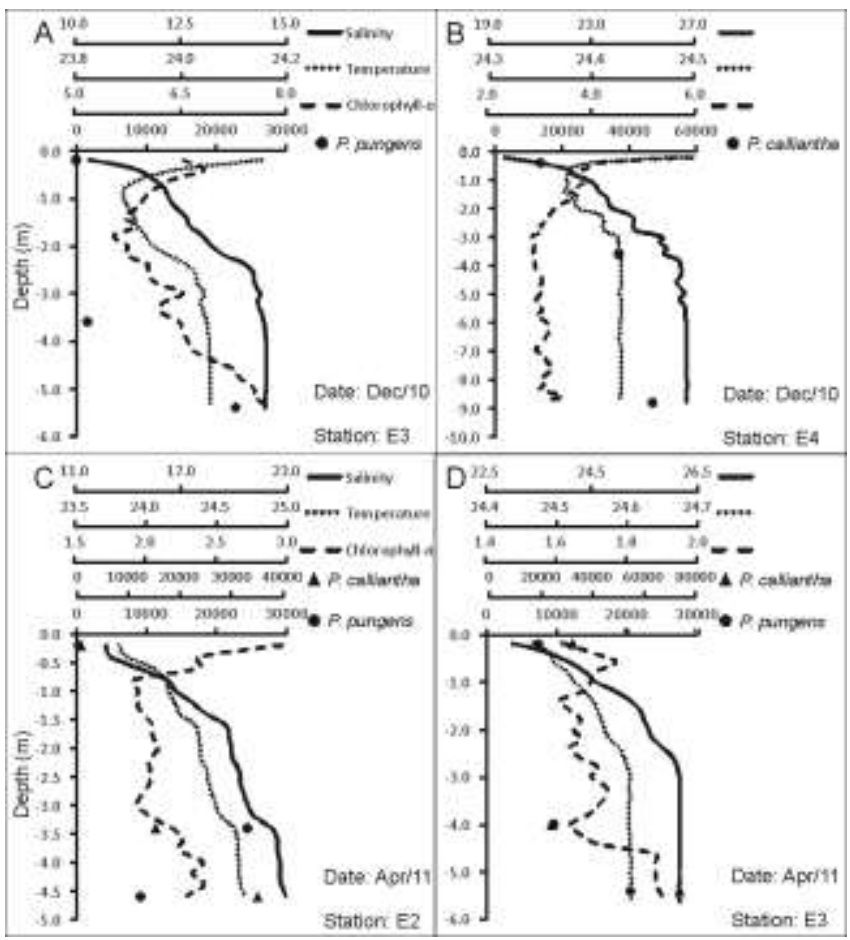

Fig. 9. Vertical profiles of salinity, temperature $\left({ }^{\circ} \mathrm{C}\right)$, chlorophyll- $a$ concentration $\left(\mu \mathrm{g} \mathrm{L}^{-1}\right.$ ) and abundance (cells L $\mathrm{L}^{-1}$ ) of Pseudo-nitzschia calliantha and P. pungens at selected sampling dates in Guaratuba Bay.

D. acuminata reached up to $3.2 \times 103$ cells $\mathrm{L}-1$, with the maximum abundance values coinciding with salinities from 10 to 25 (Fig. 10) and occurring between August and December (Fig. 11). Canonical analysis grouped $D$. acuminata with certain nontoxic species that were moderately frequent in the samples (e.g. Asterionellopsis glacialis, Chaetoceros spp. and Thalassionema nitzschioides), under conditions of greater salinity, turbidity and DIN concentration (Fig. 5). However, greater cell densities of $D$. acuminata were found near the surface and above the haline stratification of the water column, unlike the co-occurring diatoms that were observed at higher abundances mainly below the haline stratification (Fig. 12).

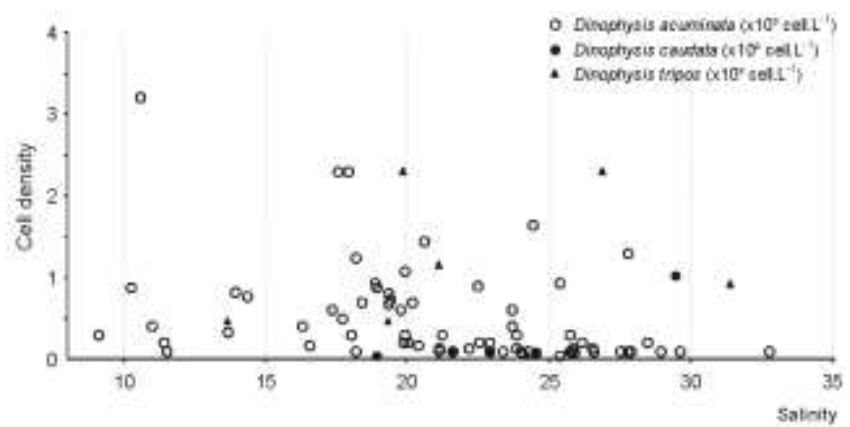

Fig. 10. Cell abundance of three potentially toxic Dinophysis species versus salinity in all samples where they occur $(n=73)$ in Guaratuba Bay, PR, from October 2010 to April 2012. 
D. caudata reached up to $1.0 \times 103$ cells $\mathrm{L}^{-1}$ at a salinity of 30, and occurred only in samples with a salinity greater than 22 (Fig. 10), in September 2011 and April 2012, when total phytoplankton abundances were higher (Fig. 11). Additionally, low abundances of D. tripos (up to 200 cells $\mathrm{L}^{-1}$ ) were reported mainly in samples with salinity between 20 and 28 (Fig. 10). Similar to D. caudata, D. tripos occurred only in September 2011 and April 2012 (Fig. 11). In the CCA,
D. caudata, D. tripos and two species of marine diatoms (Helicotheca sp. and Thalassiothrix sp.) were grouped together under conditions of low rainfall, which were associated with samples collected in April 2012 (Fig. 5). In addition, greater cell densities of $D$. caudata were found at the surface of the water column, whereas $D$. tripos was dominant either at the surface or associated with deeper high-chlorophyll- $a$ layers (Fig. 13).

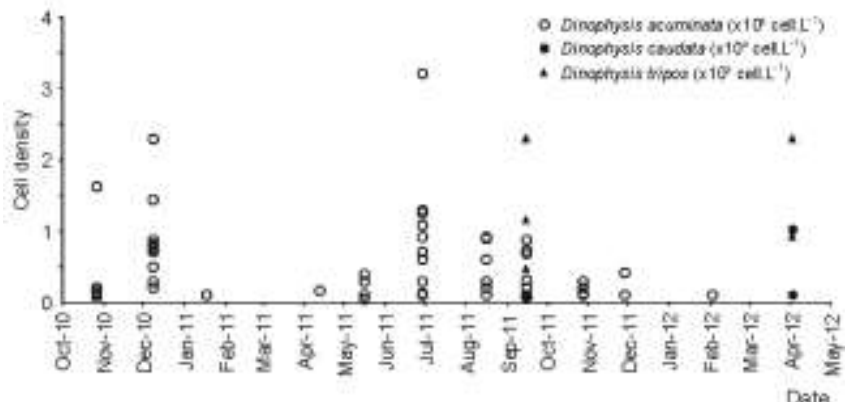

Fig. 11. Cell abundance of Dinophysis spp. in samples collected at each of the 15 sampling campaigns in Guaratuba Bay, PR.

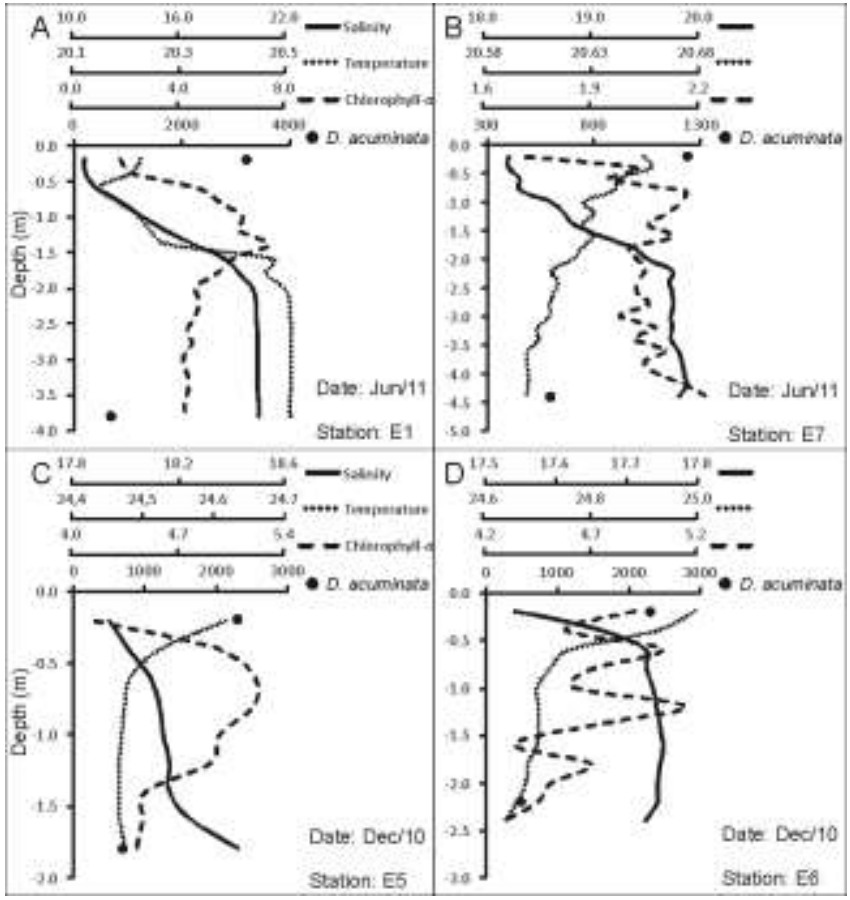

Fig. 12. Vertical profiles of salinity, temperature $\left({ }^{\circ} \mathrm{C}\right)$, chlorophyll- $a$ concentration $\left(\mu \mathrm{g} \mathrm{L}^{-1}\right)$, and abundance (cells $\mathrm{L}^{-1}$ ) of Dinophysis acuminata (X-axis) in selected samples of Guaratuba Bay. 


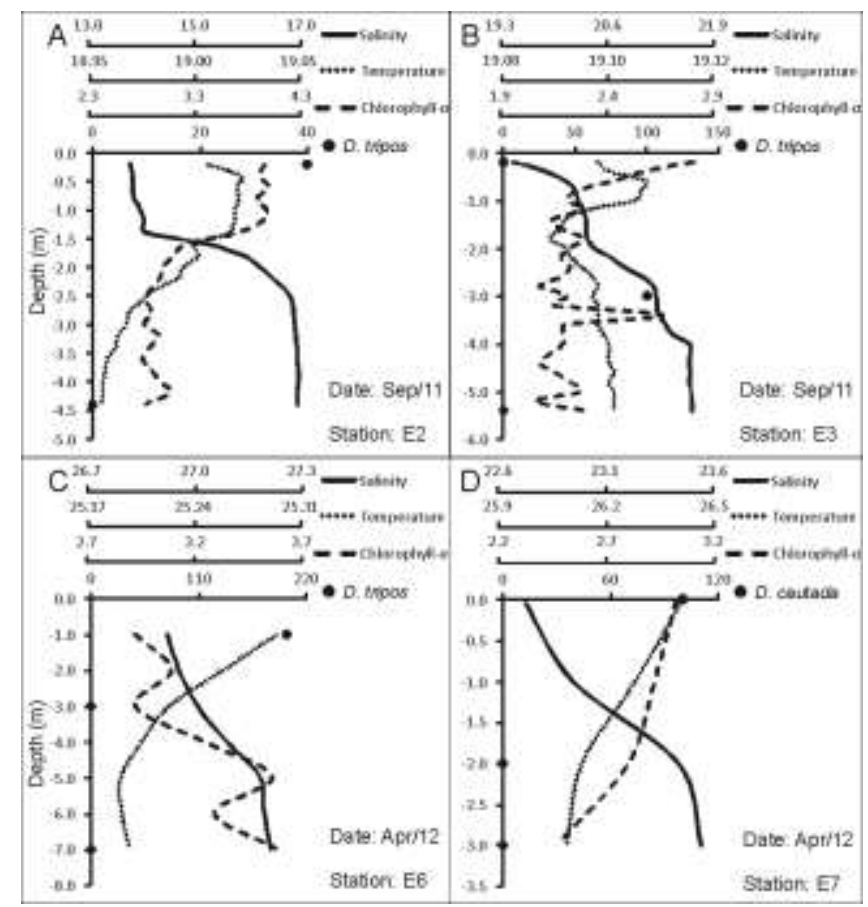

Fig. 13. Vertical profiles of salinity, temperature $\left({ }^{\circ} \mathrm{C}\right)$, chlorophyll- $a$ concentration $\left(\mu \mathrm{g} \mathrm{L}^{-1}\right)$ and abundance (cells L- ${ }^{-1}$ ) of Dinophysis tripos (A-C) and Dinophysis caudata (D) in selected samples from Guaratuba Bay.

\section{Discussion}

\section{Pseudo-nitzschia spp.}

In Guaratuba Bay, the maximum abundances of $P$. calliantha and $P$. pungens were detected from October to April, and were typically associated with an increase in temperature at locations with higher salinity (between 18 and 27, predominantly above 22) and a greater silicate availability. The higher rainfall observed in Guaratuba Bay during that period most likely increased the silicate input to the bay through continental drainage. As shown in the CCA, the more saline waters exhibited higher Pseudo-nitzschia spp. cell densities, especially when considering the absolute values measured near the bottom, where cells accumulated. This genus also occurred in conditions of lower salinity (16-25) during periods of high rainfall, but always near the bottom and in the estuary region with the greatest marine influence (the outer sector).

In other places in the world, similar results were found regarding the distribution of Pseudonitzschia spp. as a function of temperature and salinity. THESSEN et al. (2005), who investigated the seasonal dynamics of Pseudo-nitzschia in different environments (estuaries, bays and the outer shelf) along the coast of Louisiana, USA, demonstrated the affinity of $P$. calliantha for more saline waters. In that study, $P$. calliantha (identified as $P$. pseudodelicatissima) and $P$. pungens were abundant in samples with salinities ranging from 20 to 35 , although occurring in lower salinity areas as well. $P$. pungens was particularly more abundant in waters with salinities higher than 30 . In general, when isolated cells were tested in laboratory growth experiments, the optimal range of salinity (15 to 30$)$ closely overlapped that observed in the field (THESSEN et al., 2005). In the high-salinity (33-38) waters of Lim Bay, in the Adriatic Sea, P. calliantha blooms (up to $1.6 \times 106$ cells $\mathrm{L}^{-1}$ ) are mainly associated with a temperature increase during the transition from spring to summer, aside from other factors, such as phosphorus and ammonium inputs, especially at the end of summer, when aquaculture activities are more intense (LJUBESIC et al., 2011).

In the present study, Pseudo-nitzschia calliantha and $P$. pungens occurred preferentially in summer and at the beginning of the fall, between December and April, a recurrent seasonal pattern in southern Brazil (RÖRIG et al., 1998; MAFRA Jr. et al., 2006; TAVARES et al., 2009). During that period, temperatures varied from 22 to $32^{\circ} \mathrm{C}$, with the greatest cell densities observed in temperatures around $24^{\circ} \mathrm{C}$. 
The species found in this study are regarded as eurythermic (THESSEN; STOECKER, 2008; QUIJANO-SCHEGGIA et al., 2008; LIEFER et al., 2009; ANDERSON et al., 2010; LJUBESIC et al., 2011). The euryhaline and eurythermic features of both species pose serious potential implications for aquaculture. Our results, supported by the literature data, suggest that Pseudo-nitzschia spp. are potential threats to local shellfish farms, since they occur at harmful cell abundances mainly at the end of summer, coincidently with the peak of tourism and shellfish sales in the region.

Simultaneously with the variations in salinity and temperature during the rainy season, increasing silicate concentrations (and slightly higher nitrogen concentrations) were recorded during the peaks of Pseudo-nitzschia spp. abundance in Guaratuba Bay. The formation of a haline stratification in this estuary is also more evident in summer due to the increased freshwater input (our results; MIZERKOWSKI et al., 2012), which indicates the relevance of rainfall in the population dynamics of the Pseudo-nitzschia spp. in Guaratuba Bay. SPATHARIS et al. (2007) also correlated $P$. calliantha blooms in Kalloni Gulf, Greece, to periodic freshwater inputs, which bring silicate and reduce the salinity to a level closer to the optimum for the growth of these algae. As such, blooms of Pseudo-nitzschia spp. are common after large nutrient inputs, even if these blooms occur occasionally during local oscillations in salinity (MAFRA Jr. et al., 2006; LIEFER et al., 2009; PIEDRAS; ODEBRECHT, 2012).

On some occasions, macronutrients can become limiting for the growth of Pseudo-nitzschia spp. For example, SPATHARIS et al. (2007) found a marked increase in $P$. calliantha abundance immediately after a period of intense rainfall in Kalloni Gulf, Greece. The higher concentrations of nutrients, particularly phosphorus, were attributed to the intensification of agricultural activities and resulted from the application of fertilizers to cultivated lands before the most intense period of rainfall. In other marine areas, an inverse relation between macronutrient concentration and phytoplankton abundance has also been found; however, this apparently contradictory result can be explained by the excessive consumption of phosphorus and nitrogen by rapidly growing phytoplankton (FISHER et al., 1988). In Chesapeake Bay, USA, FISHER et al. (1988) observed that the silicate, nitrate and phosphate concentrations depleted mainly by virtue of the increase in phytoplankton biomass, whereas the nitrite and ammonia concentrations were more affected by regeneration and nitrification. For phosphate, a similar pattern was observed in Guaratuba Bay, probably leading to growth limitation as a result of a shortage of this nutrient.

The highest cell densities of Pseudonitzschia were found at the sampling stations located in the outer sector of the bay, decreasing drastically towards the inner sectors. Similar results were found in other environments with comparable geomorphological characteristics, such as bays and coastal inlets (THESSEN et al., 2005; SPATHARIS et al., 2007). For example, in Chesapeake Bay, USA, the most abundant toxin-producing species, $P$. calliantha, $P$. pungens and $P$. multiseries, occurred in elevated cell densities near the estuary mouth; but they were absent in areas with salinity $<6.0$ in the inner sectors (THESSEN; STOECKER, 2008). This pattern suggests that the abundance of Pseudo-nitzschia spp. near Guaratuba Bay should increase mainly outside the estuary, in the adjacent coastal zone (BRANDINI; FERNANDES, 1996), and that the cells are advected by coastal waters into the estuary at certain periods, which explains the higher abundances found below the halocline and in the outer sector of the estuary, where coastal water prevails. Although Pseudo-nitzschia spp. are usually observed close to the mouth of estuaries (SPATHARIS et al., 2007; THESSEN; STOECKER, 2008), they can also occur at lower salinities, as was the case in several areas of Chesapeake Bay with salinities up to 6 (THESSEN; STOECKER, 2008) and in the present study, where they were observed at salinities as low as 14 .

In Guaratuba Bay, two widely dominant Pseudo-nitzschia species showed a typical annual variation, with maximum abundances ranging from 2.6 to $7.3 \times 104$ cells $L^{-1}$ between December 2010 and April 2011. These densities are not sufficient to be characterized as blooms, but are already considered dangerous because of the potential risk for shellfish contamination (MAFRA Jr. et al., 2006). Such cell densities can indicate an "alert" situation in monitoring programs during which the frequency and number of samples collected for cell counts should be intensified (CIDASC, 2012). When cell abundance reaches $10 \times 104$ cells $\mathrm{L}^{-1}$, toxin analysis in bivalve mollusks is also recommended because at such a level, DA concentrations in mollusk tissues can already be sufficient to poison humans, if the cells are producing and retaining reasonable amounts of toxins (MAFRA Jr. et al., 2006; PROENÇA et al., 2011).

Despite the low Pseudo-nitzschia concentrations usually measured in the bay, we cannot rule out the risk of blooms' existing, since other triggering environmental conditions such as adequate temperature, salinity and silicate levels are simultaneously present in the bay. Moreover, it is likely that high cell abundances (> 106 cells $\mathrm{L}^{-1}$ ) can be achieved and transported from the adjacent coastal waters into the outer portion of the estuary. Indeed, 
blooms of Pseudo-nitzschia have previously been recorded in areas near Guaratuba Bay. In Paranaguá Bay, approximately $40 \mathrm{~km}$ north of Guaratuba Bay, Pseudo-nitzschia comprises an important fraction of the phytoplankton biomass, sometimes dominating the community (BRANDINI; THAMM, 1994; MAFRA Jr. et al., 2006). Additionally, blooms of $P$. multiseries and $P$. calliantha, both toxin-producing species, were recorded in the coastal areas in front of Guaratuba Bay in early summer in 1997 and 1999, from December to February in both years (FERNANDES; BRANDINI, 2010). During those periods, the intrusion of nutrient-rich waters resulting from the upwelling of the South Atlantic Central Water was regarded as responsible for the blooms (BRANDINI et al., 2007). Farther south in the state of Santa Catarina, the entire coastal region from São Francisco do Sul to the south of Santa Catarina Island has been identified as a hotspot for this genus (FERNANDES et al., 2013). That is, the area presents high species diversity, frequent blooms and previous reports of domoic acid accumulation in cultivated mollusks (PROENÇA et al., 2011). Cell concentrations as high as $21 \times 106$ cells $\mathrm{L}^{-1}$, associated with increased DA levels in mollusk tissues (up to $98.5 \mu \mathrm{g}$ g-1 in the mussel Perna perna), were recorded in some areas in January and February of 2009 (FERNANDES et al., 2013). The entire coastal area around Guaratuba Bay thus constitutes a potential seeding area for Pseudonitzschia cells, which can be transported into the bay by tides and coastal currents, the main exchange mechanisms between the bay and the adjacent coastal waters (MARONE et al., 2006).

\section{Dinophysis spp.}

In this study, three toxin-producing species of Dinophysis (D. acuminata, D. caudata and D. tripos) were recorded, with $D$. acuminata being the dominant one, occurring frequently throughout the study period at abundances of up to $3.2 \times 10^{3}$ cells $\mathrm{L}^{-1}$. Because of its high cellular diarrhetic toxin content (i.e., cell quota), D. acuminata can be harmful to humans in abundances as low as $1.0 \times 10^{3}$ cells $\mathrm{L}^{-1}$ (reviewed in Reguera et al., 2014). Even lower abundances can cause episodes of intoxication (e.g., 100-200 cells $\mathrm{L}^{-1}$; YASUMOTO et al., 1985), especially in situations that favor the retention of high toxin quotas in the cells, such as growth limitation due to the lack of prey or light (NIELSEN et al., 2012; MAFRA et al., 2014). Thus, although D. acuminata did not dominate the phytoplankton assemblage at any particular point, on several occasions the abundance of this species was greater than the alert threshold established by monitoring programs such as Brazil's (CIDASC, 2012). It is recommended, therefore, that toxin analyses of bivalve mollusks should be carried out systematically in Guaratuba Bay. The cell densities recorded in the present study suggest that the concentration of toxins in mollusk tissues from Guaratuba Bay may occasionally be sufficient to intoxicate humans (PROENÇA et al., 2011).

D. acuminata showed an irregular pattern of seasonal variation, occurring in different months during winter, spring and summer. The CCA results and the additional analyses indicated that none of the parameters evaluated could alone adequately explain the seasonal variation of $D$. acuminata in Guaratuba Bay. This finding can possibly be explained by the complex mode of energy uptake of this species. $D$. acuminata is mixotrophic and captures its prey, the ciliate Myrionecta rubra, by inserting a peduncle that immobilizes it and, after a certain time, sucks the cell content of the prey through that same structure (PARK et al., 2006). Thus, the main factors affecting the growth of this species appears to be the quality and quantity of prey (TONG et al., 2010; REGUERA et al., 2012), although pH (PARK et al., 2006), temperature (TONG et al., 2010) and light may also be factors of great relevance for the development of $D$. acuminata (REGUERA et al., 2012). In the present study, M. rubra was observed in $67 \%$ of the samples collected (data not shown); however, the cell counts of this ciliate would not be sufficiently accurate because of the sampling preservation methodology employed in this study. Because of its frequency of occurrence in the samples, $M$. rubra is most likely an important food source for Dinophysis spp. in Guaratuba Bay, and its availability probably affects $D$. acuminata distribution and abundance patterns.

Under suitable conditions, growth of $D$. acuminata in the laboratory can be equated with that of other mixotrophic dinoflagellates (KAMIYAMA; SUZUKI, 2009), although $D$. acuminata may normally be characterized as a slow-growing species. However, this species can further reduce its rate of cell division and cell size to enable it to persist in the water column in the absence of prey, demonstrating a high adaptive capacity (REGUERA et al., 2012). Thus, Dinophysis is a genus with highly persistent species that can easily multiply in the presence of light and prey, but can also slow their growth rate considerably when food is lacking (REGUERA et al., 2012). These ecological strategies could, therefore, explain the occurrence of D. acuminata all year round in Guaratuba Bay.

Additionally, in the present study, no regular pattern of spatial distribution was observed for $D$. acuminata, since high cell abundances were recorded across all sampling stations. The species was mainly recorded in salinities between 10 and 25. Considering the quite distinct environmental conditions of the stations sampled and the strong dynamics of Guaratuba Bay (MARONE et al., 2006), the use of fixed sampling points (geographic coordinates) can 
hinder the interpretation of spatial data over time. Even with the precaution of always sampling during the same astronomical tide condition, as adopted in this study (in this case at high tide), variations in the rainfall, tidal amplitude, winds and meteorological tides among the different sampling campaigns can potentially result in different current patterns, suggested by the variability in stratification throughout the study (e.g., Figs. 12 and 13). The variation in surface and subsurface currents is highly relevant because the transport of blooms is one of the factors determining the occurrence of harmful events involving Dinophysis (TAVARES et al., 2009; REGUERA et al., 2012). Any monitoring program in this area that includes this important toxigenic species should take these factors into account. The frequent occurrence of $D$. acuminata above the halocline, mainly at stations E1, E2 and E3, suggests that stratification of the water column helps in the growth of this species, as has been revealed in other studies. D. acuminata has been studied in a fjord in Chile, where its occurrence has mainly been associated with stratification and stabilization of the water column (DIAZ et al., 2011). In another study in Portugal, high abundances of this species occurred whenever the river runoff was low, associated with high salinities and water column stability (VALE; SAMPAYO, 2003). Other investigations have also confirmed that cell densities of Dinophysis spp. begin to increase as the water column stabilizes (REGUERA et al., 2012). The present study highlights the importance of water column stratification in promoting the observed cell peaks of $D$. acuminata, which has also been evidenced by a study carried out in the nearby estuarine complex of Paranaguá (MAFRA Jr. et al., 2006). This finding is important not only to understand the ecology of the species but also to determine the best methodology for its detection and enumeration, given that Dinophysis cells can migrate through the water column and concentrate in thin subsurface layers (ESCALERA et al., 2012). Aside from the use of stratified samples for better quantification, whole water column sampling, net samples and the analysis of toxins in the tissues of bivalves are recommended for a successful monitoring program focused on Dinophysis spp.

In addition to $D$. acuminata, $D$. caudata and D. tripos can also produce OA, DTXs and pectenotoxins (PTXs) (TAYLOR et al., 2004; FERNÁNDEZ et al., 2006; REGUERA et al., 2012). Of the three species, only $D$. acuminata and $D$. caudata have been associated with DSP events in various coastal water areas around the world (REGUERA et al., 2012). D. caudata occurred occasionally in Guaratuba Bay at up to $1.0 \times 10^{3}$ cells $\mathrm{L}^{-1}$ in the fall and spring. This species has already been recorded between winter and summer in southern Brazil, although never at high cell densities (RÖRIG et al., 1998; SCHMITT; PROENÇA, 2000; TAVARES et al., 2009; HARAGUCHI; ODEBRECHT, 2010). The risk of a harmful event caused by this species is low in Guaratuba Bay; however, the co-occurrence of D. caudata can potentiate the bloom toxicity of other toxic species, such as D. acuminata. The third species, D. tripos, also occurred occasionally in the bay at a maximum abundance of $0.2 \times 10^{3}$ cells $\mathrm{L}^{-1}$ during the fall and spring months. This species is present all year round in southern Brazil, although harmful events have not been recorded to date (TAVARES et al., 2009; HARAGUCHI; ODEBRECHT, 2010). Thus, similarly to $D$. caudata, $D$. tripos should be monitored in Guaratuba Bay because of its potential to cause DSP (TAYLOR et al., 2004), mainly in multi-species blooms. In addition, $D$. tripos cells are capable of retaining greater toxin quotas because they are much larger $(\sim 130 \mu \mathrm{m}$ in cell length) than $D$. acuminata $(\sim 50 \mu \mathrm{m})$ and D. caudata $(\sim 90 \mu \mathrm{m})$.

\section{Conclusions}

Based on the novel results obtained, we may affirm that Dinophysis spp. can occur throughout the year in Guaratuba Bay, with their growth most likely depending on food quality, light and water column stratification. Furthermore, the production of toxins by D. acuminata depends on the environmental conditions (LINDAHL et al., 2007; HACKETT et al., 2009). Although relatively low, the $D$. acuminata cell abundances reported herein can occasionally be sufficient for the contamination of bivalve mollusks cultivated in the bay, making the monitoring for diarrhetic toxins highly recommendable in this area.

Increases in the temperature, salinity $(>20)$ and silicate concentration favor the growth of Pseudonitzschia spp. in this estuary. However, phosphate limitation likely prevented these species from attaining cell densities high enough to threaten fishing and aquaculture activities in the region. Higher cell densities of Pseudo-nitzschia spp. within the estuary depend on the existence of a cell seeding mechanism in the adjacent coastal region and its advection into the bay. The monitoring of these species in Guaratuba Bay is desirable since blooms of these harmful diatoms have previously been recorded in adjacent waters.

\section{ACKNOWLEDGEMENTS}

The authors would like to thank the National Council of Scientific and Technological Development (CNPq, project no. 481759/2010-7) and the Araucária Foundation for the financial support provided for L. L. M. Jr. In addition, this study was partially funded by the CNPQ/PROTAX under contract no. 562151/20109. Our gratitude is also extended to the Paraná Institute 
of Technical Assistance and Rural Extension (EMATER-PR) for their assistance during sampling campaigns and to Dr. Eunice da Costa Machado and the technician Liciane Siqueira of the Center for Marine Studies (CEM), Federal University of Paraná, for their assistance with nutrient analysis. Electron microscope assistance was provided by the Center of Electron Microscopy - UFPR.

\section{REFERENCES}

ANDERSON, C. R.; SAPIANO, M. R. P.; PRASAD, M. B. K.; LONG, W.; TANGO, P. J.; BROWN, C. W.; MURTUGUDDE, R. Predicting potentially toxigenic Pseudo-nitzschia blooms in the Chesapeake Bay. J. Mar. Syst., v. 83, p. 127-140, 2010.

APHA - American Public Health Association. Standard Methods for the Examination of Water and Wastewater. Washington: American Public Health Association, 1496 pp., 1999.

BALDAN, A. P.; BENDHACK, F. Maricultura sustentável no litoral do Paraná, Brasil: atualidades e perspectivas. Rev. Acad. Ciênc. Agrár. Ambient., v. 7, n. 4, p. 491497, 2009.

BELTRÁN, A. S.; PALAFOX-URIBE, M.; GRAJALESMONTIEL, J.; CRUZ-VILLACORTA, A.; OCHOA, J. L. Sea bird mortality at Cabo San Lucas, Mexico: evidence that toxic diatom blooms are spreading. Toxicon, v. 35, n. 3, p. 447-453, 1997.

BRANDINI, F. P.; THAMM, C. A. C. Variações diárias e sazonais do fitoplâncton e parâmetros ambientais na Baía de Paranaguá. Nerítica, v. 8, n. 2, p. 55-72, 1994.

BRANDINI, F. P.; FERNANDES, L. F. Microalgae of the continental shelf off Paraná State, southeastern Brazil: a review of studies. Rev. bras. oceanogr., v. 44, n. 1, p. 69-80, 1996.

BRANDINI, F. P.; SILVA, A. S.; SILVA, E. T.; KOLM, H. Sources of Nutrients and Seasonal Dynamics of Chlorophyll on the Inner Shelf off Paraná State-South Brazil Bight. J. Coast. Res., v. 23, n. 5, p. 1131-1140, 2007.

CARVALHO, M.; JACINTO, J.; RAMOS, N.; OLIVEIRA, V.; MELO, T. P.; SÁ, J. Paralytic shellfish poisoning: clinical and electrophysiological observations. J. Neurol., v. 245, p. 551-554, 1998.

CIDASC - COMPANHIA INTEGRADA DE DESENVOLVIMENTO AGRÍCOLA DE SANTA CATARINA. Monitoramento de Algas Nocivas. Disponível em: Acesso em: 06 ago. 2012.

DARANAS, A. H.; NORTE, M.; FERNÂNDEZ, J. J. Toxic marine microalgae. Toxicon, v. 39, p. 1101-1132, 2001.

DAY JR., J. W.; HALL, C. A. S.; KEMP, W. M.; YÁÑEZARANCIBIA, A (Ed.). Estuarine ecology. John Wiley, $1989,558 \mathrm{p}$.

DIAZ, P.; MOLINET, C.; CACERES M. A.; VALLELEVINSON, A. Seasonal and intratidal distribution of Dinophysis spp. in a Chilean fjord. Harmful Algae, v. 10, p. 155-164, 2011.

EDLER, L.; ELBRÄCHTER, M., The Utermöhl method for quantitative phytoplankton analysis. In: KARLSON, B.; CUSACK, C.; BRESNAN, E. (Eds). Microscopic and molecular methods for quantitative phytoplankton analysis. Paris: Intergovernmental Oceanographic Commission of UNESCO, 2010, p. 13-20.

ESCALERA, L.; PAZOS, Y.; DOVAL, M. D.; REGUERA, B. A comparison of integrated and discrete depth sampling for monitoring toxic species of Dinophysis. Mar. Pollut. Bull., v. 64, p. 106-113, 2012.

ETHERIDGE, S. M. Paralytic shellfish poisoning: Seafood safety and human health perspectives. Toxicon, v. 56, p. $108-122,2010$

FERNANDES, L. F.; BRANDINI, F. P. The potentially toxic diatom Pseudo-nitzschia H. Peragallo in the Paraná and Santa Catarina States, Southern Brazil. Iheringia, Ser. Bot., v. 65, n. 1, p. 47-62, 2010.

FERNANDES, L. F.; CAVALCANTE, K. P.; PROENÇA, L. A. O.; SCHRAMM, M. A. Blooms of Pseudonitzschia pseudodelicatissima and $P$. calliantha and associated domoic acid accumulation in shellfish from the South Brazilian coast. Diatom Research, v. 28:381393, 2013.

FERNÁNDEZ, M. L.; REGUERA, B.; GONZÁLEZ-GIL, S.; MÍGUEZ, A. Pectenotoxin-2 in single-cell isolates of Dinophysis caudata and Dinophysis acuta from the Galician Rías (NW Spain). Toxicon, v. 48, p. 477-490, 2006.

FISHER, T. R.; HARDING JR, L. W.; STANLEY, D. W.; WARD, L. G. Phytoplankton, Nutrients, and Turbidity in the Chesapeake, Delaware, and Hudson Estuaries. Estuar. Coast. Shelf Sci, v. 27, p. 61-93, 1988.

GERSSEN, A.; POL-HOFSTAD, I. E.; POELMAN, M.; MULDER, P. P. J.; TOP, H. J. VAN DEN; BOER, J. Marine Toxins: Chemistry, Toxicity, Occurrence and Detection, with Special Reference to the Dutch Situation. Toxins, v. 2, p. 878-904, 2010.

GRANT, K. S.; BURBACHER, T.M.; FAUSTMAN, E.M.; GRATTTAN, L. Domoic acid: Neurobehavioral consequences of exposure to a prevalent marine biotoxin. Neuro Tox. Teratol., v. 32, p. 132-141, 2010.

HACKETT, J. D.; TONG, M.; KULIS, D. M.; FUX, E.; HESS, P.; BIRE, R.; ANDERSON, D. M. DSP toxin production de novo in cultures of Dinophysis acuminate (Dinophyceae) from North America. Harmful Algae, v. 8, p. 873-879, 2009.

HARAGUCHI, L.; ODEBRECHT, C. Dinophysiales (Dinophyceae) no extremo Sul do Brasil (inverno de 2005, verão de 2007). Biota Neotrop., v. 10, n. 3, p. 101-114, 2010

HASLE, G. R.; FRYXELL, G. A.; Diatoms: cleaning and mounting for light and electron microscopy. Trans. Am. Microscop. Soci., v. 89, p. 469-474, 1970.

HOLM-HANSEN, O.; LORENZEN, C. J.; HOLMES, R. W.; STRICKLAND, J. D. H. Fluorimetric determination of chlorophyll. ICES J. Mar. Sci., v. 30, n. 1, p. 3-15, 1965.

IAPAR - INSTITUTO AGRONÔMICO DO PARANÁ. Cartas Climáticas do Paraná. Disponível em: Acesso em: 06 dez. 2012.

INMET - INSTITUTO NACIONAL DE METEOROLOGIA. BDMEP: Banco de Dados Meteorólogicos para Ensino e Pesquisa. Disponível em: Acesso em: 06 dez. 2012.

JEFFERY, B.; BARLOW, T.; MOIZER, K.; PAUL, S.; BOYLE, C. Review: Amnesic shellfish poison. Food Chem. Toxicol., v. 42, p. 545-557, 2004. 
KAMIYAMA, T.; SUZUKI, T. Production of dinophysistoxin-1 and pectenotoxin-2 by a culture of Dinophysis acuminata (Dinophyceae). Harmful Algae, v. 8, p. 312-317, 2009.

LEFEBVRE, K. A.; POWELL, C. L.; BUSMAN, M.; DOUCETTE, G. J.; MOELLER, P. D. R.; SILVER, J. B.; MILLER, P. E.; HUGHES, M. P.; SINGARAM, S.; SILVER, M. W.; TJEERDEMA, R. S. Detection of Domoic Acid in Northern Anchovies and California Sea Lions Associated with an Unusual Mortality Event. Natural Toxins, v. 7, p. 85-92, 1999.

LIEFER, J. D.; MACINTYRE, H. L.; NOVOVESKÁ, L.; SMITH, W. L.; DORSEY, C. P. Temporal and spatial variability in Pseudo-nitzschia spp. in Alabama coastal waters: A "hot spot" linked to submarine groundwater discharge?. Harmful Algae, v. 8, p. 706714, 2009.

LINDAHL, O; LUNDVE, B; JOHANSEN, M. Toxicity of Dinophysis spp. in relation to population density and environmental conditions on the Swedish west coast. Harmful Algae, v. 6, p. 218-231, 2007.

LJUBESIC, Z.; BOSAK, S.; VILICIC, D.; BOROJEVIC, K. K.; MARIC, D.; GODRIJAN, J.; UJEVIC, I.; PEHAREC, P.; DAKOVAC, T. Ecology and taxonomy of potentially toxic Pseudo-nitzschia species in Lim Bay (north-eastern Adriatic Sea). Harmful Algae, v. 10, p. 713-722, 2011.

MAFRA JR, L. L.; FERNANDES, L. F.; PROENÇA, L. A. O. Harmful Algae and Toxins in Paranaguá Bay, Brazil: Bases for Monitoring. Braz. J. Oceanogr., v. 54, n. 1, p. 107-121, 2006.

MAFRA JR., L. L. ; BRICELJ, V. M.; OUELLETTE, C.; BATES, S. S. Feeding mechanics as the basis for differential uptake of the neurotoxin domoic acid by oysters, Crassostrea virginica, and mussels, Mytilus edulis. Aquatic Toxicology, v. 97, p. 160-171, 2010.

MAFRA JR., L. L.; TAVARES, C. P. S.; SCHRAMM, M. A. Diarrheic toxins in field-sampled and cultivated Dinophysis spp. cells from southern Brazil. J. applied Phycol., v. 26, n. 4, p. 1727-1739, 2014.

MARINÉ, G. F.; SILVA, P. P. O.; OLIVEIRA, G. M.; FERREIRA, V. M. Detecção de ácido ocadaico em cultivo de mexilhões Perna perna, Angra dos Reis, RJ. Cienc. Rural, v. 40, n.1, Santa Maria, 2009.

MARONE, E.; NOERNBERG, M. A.; SANTOS, I.; LAUTERT, L. F.; ANDREOLI, O. R.; BUBA, H.; FILL, H. D. Hydrodynamics of Guaratuba Bay, PR, Brazil. J. Coast. Res., v. 39, p. 1879-1883, 2006.

MIZERKOWSKI, B. D.; MACHADO, E. C.; BRANDINI, N.; NAZARIO, M. G.; BONFIM, K. V. Environmental water quality assessment in Guaratuba Bay, State of Paraná, Southern Brazil. Braz. J. Oceanogr., v. 60, n. 2, p. 107-118, 2012.

NIELSEN, L. T.; KROCK, B.; HANSEN, P. J. Effects of light and food availability on toxin production, growth and photosynthesis in Dinophysis acuminata. Mar. Ecol. Prog. Ser., v. 471, p. 37-50, 2012.

ODEBRECHT, C.; AZEVEDO, S. M. F. O.; GARCIA, V. M. T.; HUSZAR, V. L. M.; MAGALHAES, V. F.; MENEZES, M.; PROENÇA, L. A. O.; RÖRIG, L. R.; TENENBAUM, D. R.; VILLAC, M. C.; YUNES, J. S. Floraciones de microalgas nocivas en Brasil: estado del arte y proyectos en curso. In: SAR, E. A.; FERRARIO, M. E.; REGUERA, B. (Ed.). Floraciones Algales
Nocivas en el Cono Sur Americano. Vigo: Instituto Español de Oceanografia, 2002, p. 217-233.

PARK, M. G.; KIM, S.; KIM, H. S.; MYUNG, G.; KANG, Y. G.; YIH, W. First successful culture of the marine dinoflagellate Dinophysis acuminate. Aquat. Microb. Ecol., v. 45, p. 101-106, 2006.

PERL, T. M.; BÉDARD, L.; KOSATSKY, T.; HOCKIN, J. C.; TODD, E. C. D.; REMIS, R. S. An outbreak of toxic encephalopathy caused by eating mussels contaminated with domoic acid. The New England Journal of Medicine, v. 322, n. 25, p. 1775-1780, 1990.

PIEDRAS, F. R.; ODEBRECHT, C. The response of surfzone phytoplankton to nutrient enrichment (Cassino Beach, Brazil). J. exp. Mar. Biol. Ecol., v. 432-433, p. 156-161, 2012

PROCOPIAK, L. K.; FERNANDES, L. F.; MOREIRA FILHO, H. Diatomáceas (Bacillariophyta) marinhas e estuarinas do Paraná, Sul do Brasil: lista de espécies com ênfase em espécies nocivas. Biota Neotrop., v. 6, n. 3, 28 pp., 2006.

PROENÇA, L. A. O.; MAFRA JR, L. L. Ocorrência de ficotoxinas na costa brasileira. In: Reunião Brasileira de Ficologia, X. Anais. (Série Livros do Museu Nacional, 10). Rio de Janeiro: Museu Nacional, 2005, p. 57-77.

PROENÇA, L. A. O. Algal blooms in coastal zones: examples of harmful impacts from the Brazilian coast. J. Coast. Res., v. 39, p. $76-78,2006$.

PROENÇA, L. A. O.; FONSECA, R. S.; PINTO, T. O. Microalgas em área de cultivo do litoral de Santa Catarina. São Carlos: Rima, 2011, 80 p.

QUIJANO-SCHEGGIA, S.; GARCÉS, E.; SAMPEDRO, N.; VAN LENNING, K.; FLO, E.; ANDREE, K.; FORTUÑO, J.; CAMP, J. Identification and characterisation of the dominant Pseudo-nitzschia species (Bacillariophyceae) along the NE Spanish coast (Catalonia, NW Mediterranean). Scientia Marina, v. 72, n. 2 , p. $343-359,2008$

REGUERA, B.; VELO-SUAREZ, L.; RAINE, R.; PARK, M. G. Harmful Dinophysis species: A review. Harmful Algae, v. 14, p. 87-106, 2012.

REGUERA, B.; RIOBÓ, P.; RODRÍGUEZ, F.; DÍAZ, P. A.; PIZARRO, G.; PAZ, B.; FRANCO, J. M.; BLANCO, J. Dinophysis Toxins: Causative Organisms, Distribution and Fate in Shellfish. Mar. Drugs, v. 12, p. 394-461, 2014.

REIZOPOULOU, S.; STROGYLOUDI, $\quad$ E.; GIANNAKOUROU, A.; PAGOU, K.; HATZIANESTIS, I.; PYRGAKI, C.; GRANELI, E. Okadaic acid accumulation in macrofilter feeders subjected to natural blooms of Dinophysis acuminate. Harmful Algae, v. 7, p. 228-234, 2008.

RÖRIG, L. R.; GUIMARÃES, S. C. P.; LUGLI, D. O.; PROENÇA, L. A. O.; MANZONI, G. C.; MARENZI, A. C. Monitorização de Microalgas Planctônicas Potencialmente Tóxicas na Área de Maricultura da Enseada de Armação de Itapocoroy - Penha - SC. Notas Téc. Facimar, v. 2, p. 71-79, 1998.

SANTOS, P. R. N. M.; KOLM, H. E.; SAUTTER, K. D. Bactérias em sedimentos da região entre-marés da Baía de Guaratuba, Paraná, Brasil. Braz. J. Aquat. Sci. Technol., v. 12, n. 1, p. 9-17, 2008.

SCHMITT, F.; PROENÇA, L. A. O. Ocorrência de Dinoflagelados do Gênero Dinophysis (Enrenberg, 1839) 
na Enseada de Cabeçudas (Verão e Outono de 1999). Notas Téc. Facimar, v. 4, p. 49-59, 2000.

SPATHARIS, S.; DANIELIDIS, D. B.; TSIRTSIS, G. Recurrent Pseudo-nitzschia calliantha (Bacillariophyceae) and Alexandrium insuetum (Dinophyceae) winter blooms induced by agricultural runoff. Harmful Algae, v. 6, p. 811-822, 2007.

STRICKLAND, J. D. H.; PARSONS, T. R. A practical handbook of seawater analysis. Bull. Fish. Res. bd. Canada, Ottawa, v. 167, p. 1 - 205, 1972.

TAVARES, J. F.; PROENÇA, L. A. O.; ODEBRECHT, C. Assessing the Harmful Microalgae Occurrence and Temporal Variation in a Coastal Aquaculture Area, Southern Brazil. Atlântica, v. 31, n. 2, p. 129-144, 2009.

TAYLOR, F. J. R.; FUKUYO, Y.; LARSEN, J.; HALLEGRAEFF, G. M. Taxonomy of harmful dinoflagellates. In: HALLEGRAEFF, G. M.; ANDERSON, D. M.; CEMBELLA, A. D. (Ed.). Manual on harmful marine microalgae. Paris: Monographs on oceanographic methodology 11, UNESCO, 2004, p. 389-432.

TER BRAAK, C. J. F.; SMILAUER, P. CANOCO Reference manual and CanoDraw for Windows user's guide: Software for Canonical Community Ordination (version 4.5). Ithaca: Microcomputer Power, 2002, 500p.

THESSEN, A. E.; DORTCH, Q.; PARSONS, M. L.; MORRISON, W. Effect of salinity on Pseudo-nitzschia species (Bacillariophyceae) growth and distribution. J. Phycol., v. 41, p. 21-29, 2005.
THESSEN, A. E.; STOECKER, D. K. Distribution, Abundance and Domoic Acid Analysis of the Toxic Diatom Genus Pseudo-nitzschia from the Chesapeake Bay. Estuaries and Coasts, 9 pp., 2008.

TONG, M.; ZHOU, Q.; KULIS, M. D.; JIANG, T.; QI, Y.; ANDERSON, M. D. Culture techniques and growth characteristics of Dinophysis acuminata and its prey. Chinese J. Oceanol. Limnol., v. 28, n. 6, p. 1230-1239, 2010.

TOYOFUKU, H. Joint FAO/WHO/IOC activities to provide scientific advice on marine biotoxins (research report). Marine Pollution Bulletin, v. 52, p. 1735-1745, 2006.

ÜTERMOHL, I. Zur Vervolkommnung der quantitativen Phytoplankton-Methodik. Mitt. Int. Ver. Theor. Angew. Limnol., v. 9, p. 1-38, 1958.

VALE, P.; SAMPAYO, M. A. M. Seasonality of diarrhetic shellfish poisoning at a coastal lagoon in Portugal: rainfall patterns and folk wisdom. Toxicon, v. 41, p.187197, 2003.

YASUMOTO, T.; MURATA, M.; OSHIMA, Y.; SANO, M. Diarrhetic Shellfish Toxins. Tetrahedron, v. 41, n. 6, p. 1019-1025, 1985.

(Manuscript received 22 November 2013; revised 28 September 2014; accepted 29 September 2014) 